\title{
Improved Understanding of Oceanic Processes through an Integrated Caribbean Coastal Ocean Observing System
}

\author{
R.A. Watlington ${ }^{1}$, J.M. Morell ${ }^{2}$ \& J.E. Corredor ${ }^{2}$ \\ 1. Caribbean Regional Association, University of the Virgin Islands, No.2 John Brewers Bay, St. Thomas, VI 00802; \\ rwatlin@uvi.edu \\ 2. Caribbean Regional Association, University of Puerto Rico, Department of Marine Sciences, Lajas PR 00667; \\ j_morell@cima.uprm.edu; j_corredor@cima.uprm.edu
}

Received 13-VII-2007. Corrected 01-XI-2007. Accepted 13-II-2008.

\begin{abstract}
Advances in the understanding of every oceanic process of concern to scientists, marine resource managers, disaster managers and other decision makers require improved understanding of properties such as sea surface temperature, circulation, air-land-sea interactions, sea floor bathymetry, eddy propagation and other subjects in which regional informational needs remain unfulfilled. To address this situation, the University of Puerto Rico and the University of the Virgin Islands, with the authority and support of an interagency consortium of US agencies, have organized CaRA, the Caribbean Regional Association. As part of a national system of similar organizations, CaRA is charged with advancing the state of observational platforms and related infrastructure in the region. Its mandate also calls for assembling existing data streams and inventories of databases, data management protocols, and regionally focused expertise into a sustainable, integrated observing system that improves and advances monitoring of the ocean in the Caribbean region and contributes substantially to the understanding of ocean processes. It has begun its mission by engaging regional stakeholders, identifying their needs for information about the ocean and coasts, conducting an inventory of existing ocean observing system assets, formalizing its own structure, and facilitating collaborations and pilot projects that demonstrate the utility of the integrated ocean observing concept. Rev. Biol. Trop. 56 (Suppl. 1): 89-96. Epub 2008 May 30.
\end{abstract}

Key words: CaRA, Exclusive Economic Zone, national backbone, Ocean.US, ocean observing system, regional association, stakeholder.

Connectivity among coral reefs, oceanic indicators of climate change, coral reef health, oceanic conditions for storm intensification, fisheries assessments, larval recruitment and tsunami propagation are examples of ocean processes that can be advanced with increased availability of data, modeling capabilities, scientific collaborations and with the adequate ocean observations on which these activities can be based. For example, in order to anticipate zygote or pollutant dispersal, larval recruitment or to find adrift vessels, wind-driven currents and tides must be known. Fishery and coral reef scientists struggle to achieve visualizations of ocean currents and eddies that can explain replenishment of pelagic stocks and distant habitats by upstream sources (Roberts 1997) or retention by eddy circulation (Love et al. 2003). Sea-surface temperatures are needed for estimating the oceanic heat energy available for tropical cyclone development or for correlating oceanic conditions to coral reef health. Modeling and forecasting coastal storm surge or tsunami runup requires accurate ocean floor bathymetry along with other inputs such as tidal range and winds. Many questions of scientific interest and practical importance call for improved understanding of winds, waves, currents, eddies, sea temperatures and more. To understand these disparate oceanic processes and to utilize this 
understanding for the good of the nation and of the communities in a region, a variety of ocean observations become essential.

In some cases in situ observations are needed in real time, such as in cases where search and rescue necessitate coastal wind data or, at the other extreme, when remotely sensed measurements are used to initialize ocean models that anticipate future oceanic conditions. Occasionally, such as when anticipating intrusions of spilled oil, harmful algal blooms or African dust, conclusive useful observations require both long-term satellite observations and real-time in situ measurements at the airsea interface. Systems for providing needed observations and measurement are already established, matching many of the information needs in some portions of the United States oceanic Exclusive Economic Zone (US-EEZ), which includes coastal oceans and Great Lake waters under US jurisdiction. In other regions observation systems are not adequate to meet regional information needs. The waters around Puerto Rico, the United States Virgin Islands, and the uninhabited island of Navassa comprise the Caribbean portion of the US-EEZ, and represent such a region. Its fishers, resource managers, search and rescue officials, providers of tourism-related marine recreation and ocean scientists can all cite examples when ocean information needed to function effectively was not available. Puerto Rico (PR) is a Commonwealth associated with the United States whereas the US Virgin Islands (USVI) is an unincorporated territory of the United States. Both are self-governing with respect to their internal affairs with the United States maintaining authority over foreign relations, currency, citizenship, trade and most external affairs. Navassa, located $55 \mathrm{~km}$ west of Haiti, is a $5.2 \mathrm{~km}^{2}$ islet claimed by the United States and administered by the US Fish and Wildlife Service (Asch et al. 2003).

\section{OCEAN.US AND THE IOOS CONCEPT}

With the national interests - safety, security, economy, resource management, and quality of life - at stake, ten federal agencies established an interagency office named "Ocean.US" to develop an integrated ocean observing system (IOOS) for the United States. This system is intended to "...routinely and continuously provide quality controlled data and information on current and future states [within the US-EEZ] in forms and at the times required to address the following seven societal goals:

- Improve predictions of climate change and weather and their effects on coastal communities and the nation;

- Improve the safety and efficiency of maritime operations [including recreation and tourism];

- Mitigate the effects of natural hazards more effectively;

- Improve national and homeland security;

- Reduce public health risks;

- Protect and restore healthy coastal ecosystems more effectively;

- Enable the sustained use of ocean and coastal resources”. (Ocean.US 2002)

The IOOS concept is intended to complement and support the international Global Ocean Observing System (GOOS) that has been in development since 1991. US-IOOS also encompasses regional international elements, such as in the Great Lakes where interests are shared with Canada or in the US-Caribbean where the oceanic boundaries of the United Kingdom, the Dominican Republic, Venezuela and several other nations and territories meet. At the moment the US IOOS is comprised of regional coastal ocean observation systems that are integrated to assure effective coverage of the entire US-EEZ. Some more developed and with many more technological assets than others. The complete list follows alphabetically below:

- $\quad$ Alaska Ocean Observing System (AOOS)

- Caribbean Integrated Coastal Ocean Observing System (CarICOOS)

- Central and Northern California Ocean Observing System (CeNCOOS) 
- $\quad$ Great Lakes Observing System (GLOS)

- Gulf of Maine Ocean Observing System (GOMOOS)

- Gulf of Mexico Coastal Ocean Observing System (GCOOS)

- Mid-Atlantic Coastal Ocean Observing Regional Association (MACOORA)

- Northwest Association of Networked Ocean Observing Systems (NANOOS)

- $\quad$ Pacific Island Integrated Ocean Observing System (PacIOOS)

- Southeast Coastal Ocean Observing Regional Association (SECOORA)

- Southern California Coastal Ocean Observing System (SCCOOS).

\section{THE NATIONAL BACKBONE OF OCEAN OBSERVING ASSETS}

Many sources of ocean observations and data from the vicinity of the US-Caribbean EEZ are either part of the "national backbone" (the US inventory of ocean observation elements) or are owned and operated by other nations. This inventory includes in situ instrumentation as well as remote sensing facilities. The following are data streams presently available for the US-Caribbean EEZ provided from ocean and coastal platforms and from modeling efforts:

- NOAA's National Water Level Observation Network stations

- Moored open-ocean platforms of NOAA's National Data Buoy Center

- Coral Reef Early Warning System multisensor platforms

- US Geological Survey stream gauges

- Operational modeling products from the Naval Research Laboratory and from the National Oceanic and Atmospheric Administration (NOAA)

- NOAA's National Weather Service meteorological stations and forecast modeling

- National Aeronautics and Space Administration (NASA) satellite imagery for weather, ocean circulation, sea surface temperatures, ocean color, etc.

- NOAA Deep-ocean Assessment and Reporting Tsunami (DART) buoys.

The map of Figure 1 is an illustration from the web page of NOAA's National Data

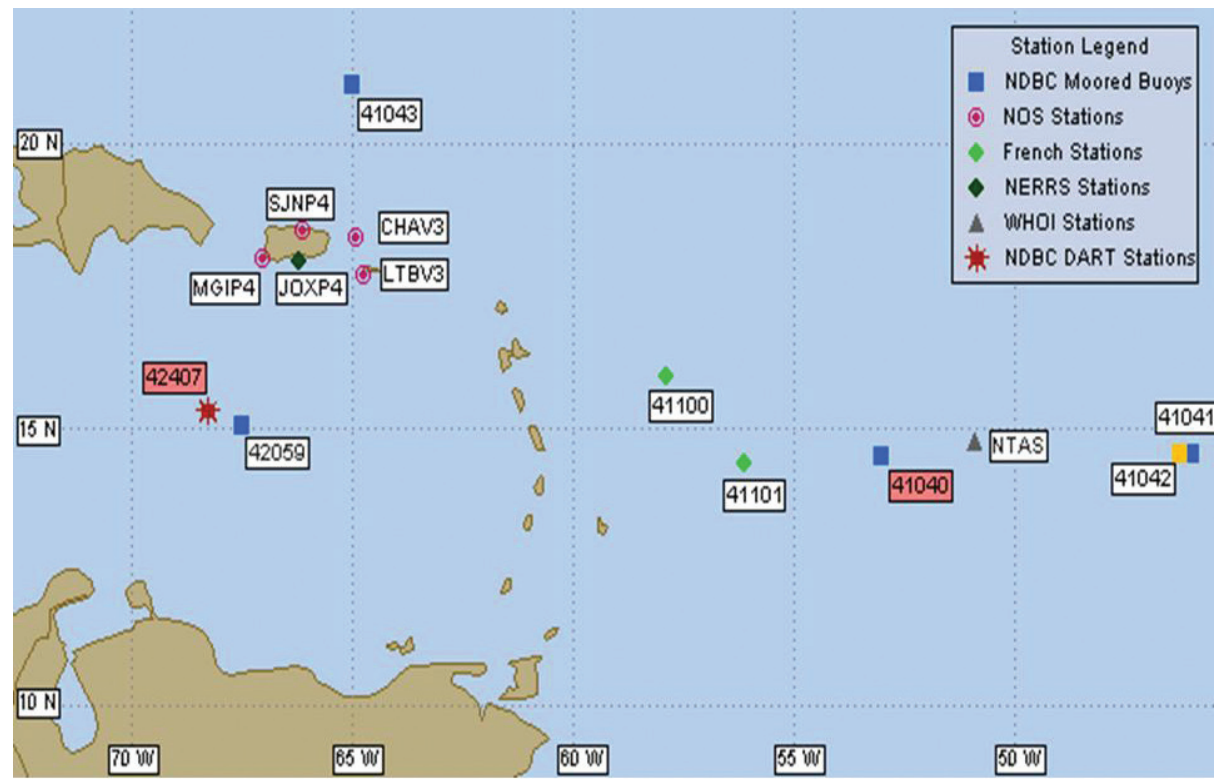

(NDBC 2007)

Fig. 1. NDBC web site of moored buoys and water level gauges in the Eastern US-Caribbean EEZ. (The NOAA identification number for each station can be clicked to open the link accessing station data.) 
Buoy Center (NDBC) that shows the location of ocean buoys, water-level (tide) gauges and other stations in the eastern Caribbean. The links for many of these stations are activated and data can be accessed. In addition, not shown but deployed approximately $300 \mathrm{~km}$ south of Navassa, NDBC Buoy \# 42058 is also operational and accessible at the NDBC web site (NDBC 2007).

\section{THE REGIONAL ASSOCIATIONS AND CARA}

To develop, implement and manage the ocean observing systems as well as additional systems and sub-systems as they may develop in the future, Ocean.US fostered the establishment of eleven regional associations under a unifying National Federation of Regional Associations (NFRA). The regional associations (RAs) are responsible for securing the following attributes for their observation system:

- Observational assets (sensors, platforms, remote sensing hardware, etc.) that provide for information needs of local and national stakeholders

- Sustainable and continuous observational programs (serial stations, time series, etc.)

- Data storage, management and processing

- Synergized regional expertise in

- modeling

- data management and communications (DMAC)

- education

- outreach

- Appropriate avenues of access for regional stakeholders

- Organization and coordination of interregional and international efforts.

Further, the RAs are responsible for identifying the needs of both private and public sectors and for transmitting these needs convincingly to Ocean.US, the NFRA, and responsible federal agencies. In this way as local observational capability improves the national backbone of observational assets is simultaneously enhanced. The RAs are also responsible for incorporating sub-regional systems as they are identified or developed. They are compelled to adhere to the principal that ocean observation systems are intended to serve the practical as well as the scientific informational needs of their regions. Ocean observing systems must be set up with data streams that serve decision makers, business persons and operators in navigation, fishing, diving, sailing as well as search and rescue officers and scientists studying coral reefs, global circulation or climate change. To ensure this adherence, the RAs must embrace full and active participation of all community sectors that are dependent on or otherwise involved with regional oceans and coasts.

The Caribbean Regional Association (CaRA) was formed in 2004 to facilitate achievement of the seven societal goals for Puerto Rico, the US Virgin Islands and Navassa. CaRA is responsible for the design, justification and operation of the Caribbean Integrated Coastal Ocean Observing System (CarICOOS) as part of the US IOOS (CaRA 2007). Its formation was entrusted to the University of Puerto Rico, Mayagüez Campus (UPRM), and the University of the Virgin Islands (UVI), supported by NOAA. As is the case for all regional associations, to preserve this authority, CaRA must achieve performance metrics, which include: legal governance structure, regional priorities reflected in the composition of engaged stakeholders, and extant observational assets. In addition to achieving structure and certification, important tasks immediately at hand include the following continuous activities:

- Identification of data users and their needs;

- Identification of data providers and their products including existing "national backbone" data streams and making them accessible to the community;

- Enhancement of data flow and communication between users and providers;

- Identification of data gaps and design systems to fill these gaps (CaRA 2006). 


\section{THE NASCENT CARICOOS}

Although a much smaller entity than any of the other regionally distinct ocean observing systems and only recently recognized, CarICOOS includes the following local sources of extant data streams:

- Programa monitoria Reserva Nacional Estuarina Jobos, Puerto Rico.

- The environmental protection branches of the Department of Natural and Environment Resources (Puerto Rico) and the Department of Planning and Natural Resources (USVI), which conduct regular water quality monitoring for beaches.

- Caribbean Time Series (CATS) serial station ( www.cats-uprm.org).

- Marine Protection Area observations and data streams in the USVI.

- Data streams from the Virgin Islands National Park in collaboration with NOAA.

- Anegada Passage climate tracers transport/ exchange serial station (ACTS).

Additional data streams from vessels of opportunity have been identified, such as those accessible from the $M V$ Explorer of the Seas. Access to other data sources from private yachts and platforms outfitted by the International SeaKeepers Society is being identified. Additional observational platforms and data sources that will enhance the CarICOOS inventory are under development. The following are examples:

- Sensors are being deployed for near surface circulation and oxygen evolution at Media Luna reef (LaParguera, Puerto Rico)

- A demonstration project for acoustic wave monitoring at a key USVI location is nearing deployment.

- A proposal for installing a HF radar system for coastal monitoring has been submitted.

\section{PROGRESS REPORT}

CaRA's progress in Years 1 and 2 has consisted of major steps in its formal organization and movement towards meeting performance metrics, in its identification and inclusion of a broad range of stakeholders, by its participation in the development of the multi-regional NFRA, and by the identification and initiation of demonstration projects in which stakeholders are significant contributors. The following recent developments are the highlights of this period:

- $\quad$ Progress in organizing CaRA and making it a legal entity:

- UPRM and UVI developed and endorsed sub-contracts to formalize their relationship and distribute federal support.

- A development grant was awarded by NOAA's Coastal Services Center.

- Draft versions of CaRA Charter, bylaws and business plan have been developed.

- CaRA signed an agreement with the Puerto Rico Sea Grant Program for the development of a comprehensive outreach program.

- The Governor's office in PR designated the Department of Natural Resources and the Environment as lead agency for CaRA activities in Puerto Rico.

- Stakeholders have been engaged and many stakeholder needs have been identified.

- Some governmental and private sector decision makers have become a part of CaRA's early structuring.

- US Fish and Wildlife officials responsible for Navassa and scientists who have been data-providers there have been contacted to participate.

- Extra-regional scientists and other data-providers who have operated in 
the region have been invited to work with CaRA and to develop synergistic relations.

- CaRA's web page with useful links to data sources from the national backbone was designed and posted and may be seen at: http:/cara.uprm.edu.

- Objective surveys have been developed and used to canvas regional stakeholders and establish their present and long-terms needs (Chaparro 2007).

- CaRA participation in NFRA activities developing the NFRA's formal structure, supporting Congressional legislation for funding continuation of IOOS and increase assets.

\section{CaRA meets the user and data providing communities}

Consistent with its mandate from Ocean. US, CaRA used its first year of funding to inform regional stakeholders of its mission and to identify their needs for ocean information. Interactive workshops were held in several areas of Puerto Rico and of the Virgin Islands and significant outreach efforts established relations with high-ranking government and private sector decision makers. These activities have continued through the second year, during which additional thrusts, such as the identification of data streams from existing ocean observational programs and the preparation of a proposal for funding implementation projects, were initiated.

The following were informational products identified in Puerto Rico and the US Virgin Islands as most essential for the coastal activities of regional stakeholders:

- Wind data and forecast (for marine operations and research);

- Sea surface temperatures (SST's) and ocean color products for weather and climate studies, commercial and sport fisheries $\&$ for assessing marine water quality;
- Current data and forecast (for research, search and rescue, SCUBA and other marine recreation);

- $\quad$ Salinity, dissolved oxygen, turbidity, nutrient concentrations, bacteriological content, and underwater visibility (for assessing water quality, recreational diving, resource management and research);

- Coastal bathymetry (for modeling storm surge \& tsunami, etc.);

- Tide data and forecast (for navigation, marine operations and research, fisheries studies);

- Wave data and forecast (for navigation and recreation);

- Habitat maps (for management and research);

- Monitoring contaminants and pollutants (for public, coral reef health);

- Saharan haze for coral reef health and marine aviation.

\section{Demonstration and pilot projects}

Several projects have been proposed as means of further demonstrating the actual and potential usefulness of CarICOOS to prospective regional stakeholders. Already CaRA has linked need to opportunity by assisting in the preparation of proposals for support to build ocean observational or data accessing capacity. A proposal has been submitted to the Department of Homeland Security for funding of a HF radar system to observe sea state, currents, waves and vessels in transit in the Mona Passage as shown in Figure 2 (Corredor 2006). Another proposal to NOAA's National Weather Service is intended to gain support for increased tsunami modeling for the region, among other goals. While preparing to recruit funds for pilot projects, CaRA has opportunistically brought a data user together with a data provider in a demonstration project that will evaluate the usefulness of an acoustic device in monitoring currents and waves in a location important for shipping and cruise ship industries. 


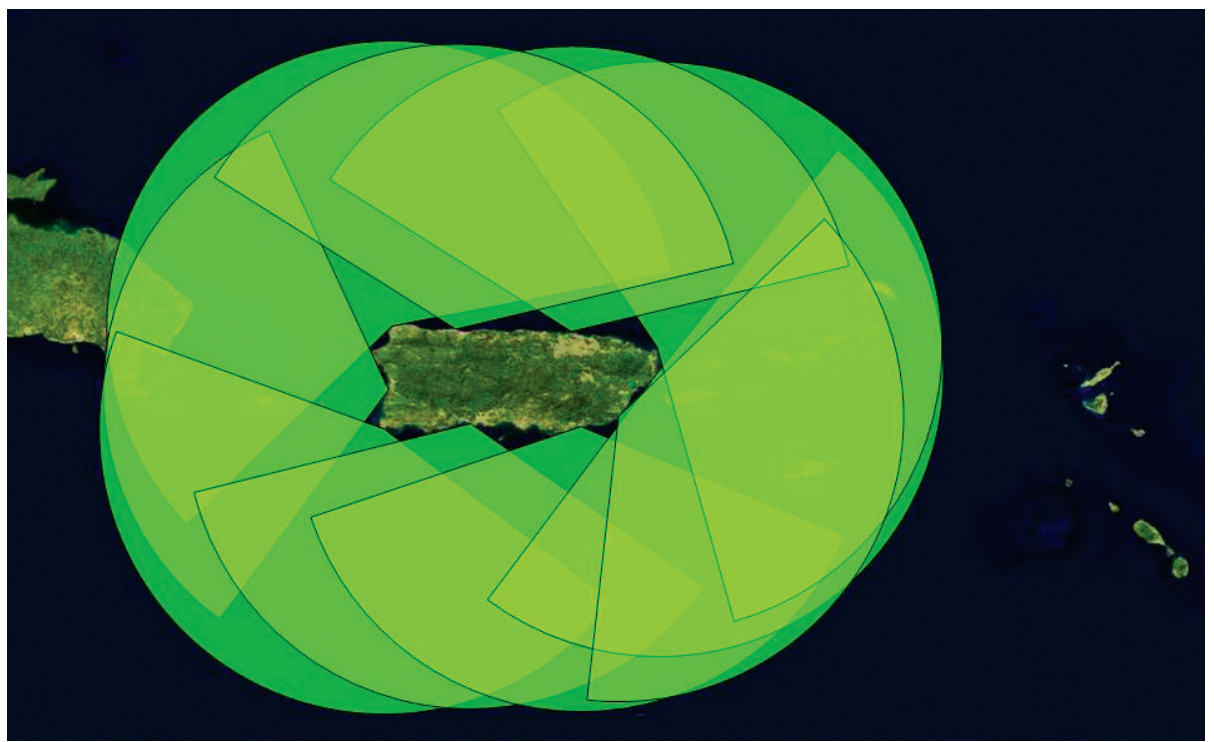

(CaRA 2007)

Fig. 2. Proposed High Frequency radar surveillance for the waters east and west of Puerto Rico.

The results of stakeholder workshops and canvassing have allowed CaRA to select two informational products for piloting the IOOS concept:

1. Winds - The most sought after informational product identified by user groups at different locations in the CaRA jurisdiction was coastal winds. Accurate wind data was requested for the recreational sector but cited as much by fishers, search \& rescue and marine transportation officials. Wind information is also useful in anticipating sea state. A number of anemometer wind gauges associated with weather stations are operational. In addition, plans exist to add wind measurements to existing sea-level gauges and other operational platforms. CaRA in association with the NOAA's National Weather Service, San Juan Office, is currently running a computer program that, together with real-time sensor data, can provide much finer, resolution for the coastal area of the islands. CaRA has agreed to provide the hardware and archival services to facilitate the devel- opment of this NWS product.

2. Turbidity - Environmental managers have expressed their need for a product that will assist in coral reef protection and resource management, e.g., matching realtime turbidity data to established criteria to recommend beach closures due to fecal contamination. As high turbidity is often correctly associated with terrestrial runoff, CaRA can match data users with existing satellite-derived products and predict water quality for human exposure. Additional existing products must be identified, accessed and optimized.

These projects have already been advanced by assembling existing regional capabilities and will be further advanced by preparing proposals for their support and inclusion as part of the federal inventory of assets.

In the US-Caribbean EEZ, improved understanding of a variety of oceanic processes could foster the solutions to important scientific and practical questions ranging from the better management of fishery stocks to the 
preservation of human life. Globally, nationally and regionally a commitment has been made to develop systems for integrated ocean observations of the oceanic variables, such as winds, currents and temperatures that drive these processes. The commitment to develop ocean observing systems for the US Exclusive Economic Zone in the Caribbean Sea has been enhanced by the creation of the Caribbean Regional Association. Formed for the purpose of establishing a Caribbean Integrated Coastal Ocean Observing System for the US Caribbean Exclusive Economic Zone it has established credibility with its national sponsors and within the other regional IOOS communities. The framework for its formal and legal structure has been defined and a strong group of initial partners has been identified. Within the region it has achieved recognition as a potentially useful entity for the many and varied users of the oceans and the coasts of Puerto Rico and the US Virgin Islands. Extant federal and regionally controlled observation assets have been identified and a process of identifying unfulfilled observational needs has been initiated. Demonstration projects have also been initiated and proposals to fund both pilot and operational projects have been fielded.

\section{RESUMEN}

La toma de decisiones administrativas informadas para el medio ambiente, comercio, manejo de desastres e investigación científica en el ambiente oceánico requiere una mejor comprensión de condiciones variables como la temperatura de la superficie del mar, la circulación, las interacciones entre el mar, la tierra y el aire, la batimetría del fondo del océano, la propagación de remolinos y otros. Estas necesidades de información están insatisfechas. Para solventar esta situación la Universidad de Puerto Rico y la Universidad de las Islas Vírgenes, con la autoridad y apoyo de un consorcio de agencias estadounidenses, han organizado la Asociación Regional del Caribe (ARCa). Como parte de un sistema nacional de organizaciones similares, la encomienda de ARCa es mejorar el estado de plataformas de observación e infraestructura existentes en la región y planificar para la instalación de nuevas plataformas con vista a las necesidades de los usuarios. También recopilar datos ya existentes e inventarios de bases de datos, fijar el protocolo para el manejo de datos y reunir expertos regionales en la integración de un sistema sostenible e integrado. Este sistema debe mejorar la observación marina operacional en la región del Caribe y contribuir a la comprensión de procesos oceánicos. ARCa ha comenzado a ejecutar su misión al reunir las partes interesadas de la región, identificando sus necesidades en cuanto a información sobre el océano y las costas, haciendo un inventario de los sistemas de observación existentes, formalizando su propia estructura y facilitando colaboraciones y proyectos piloto que demuestran la utilidad del concepto de observación oceánica integrada.

Palabras clave: CaRA, zona económica exclusiva, Ocean. US, sistema de observación de los océanos, asociación regional, actores.

\section{REFERENCES}

Asch, R.G. and D.D. Turgeon, 2003. Detection of gaps in the spatial coverage of coral reef monitoring projects in the US Caribbean and Gulf of Mexico. Rev. Biol. Trop., 51, Supl. 4: 127-140.

Ocean.US, 2002. An integrated and sustained ocean observing system (IOOS) for the US design and implementation. Ocean.US, Arlington, VA, 21pp.

Love, Milton S, Robert R. Warner and Libe Washburn, 2003. Linking early fish growth to transport and circulation using oolith microstructure and microchemistry. California Sea Grant Program, Paper Coastal 03-02, University of California, San Diego, 17 pp.

Roberts, Callum M., 1997. Connectivity and management of Caribbean coral reefs. Science, 278, No. 5342: 1454-1457.

\section{INTERNET REFERENCES}

CaRA, 2006. The mission of the Caribbean Regional Association. (Downloaded: June 4, 2007, cara.uprm. edu ).

Chaparro, Ruperto, Carlos Carrero, Maria Fernández and Manuel Valdéz Pizzini, 2007. Stakeholder canvassing and assessment of observational needs for the recreational sector. $2^{\text {nd }}$ Steering Committee Meeting, San Juan, PR, 27 April 2007 (Downloaded: June 4, 2007, cara.uprm.edu/canvas.pdf).

CaRA, 2007. CarICOOS development plan. $2^{\text {nd }}$ Steering Committee Meeting, San Juan, PR, 27 April 2007 (Downloaded: June 4, 2007: cara.uprm.edu/ Assets\%20Development\%20Plan.pdf).

NDBC, 2007. Caribbean Sea Recent Marine Data. (Downloaded: June 4, 2007, ndbc.noaa.gov/maps/ Caribbean.shtml). 